\title{
The impact of oil prices on stock exchange and CPI in Pakistan
}

\author{
Ibraheem Ansar, Mis Nadia Asghar ${ }^{1}$

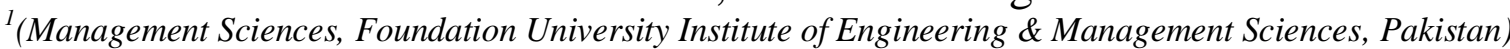

\begin{abstract}
The oil is one of the most important factors affecting the economy of the world that is why any change in the oil prices brings change in all the economic variables. For this purpose the researcher have analyzed the impact of oil prices on the Consumer Price Index (CPI) and Stock market (KSE-100 Index), For this purpose the researcher collected the data from secondary sources on CPI and KSE-100 Index from 2007 to 2012. To analyze the impact of the oil prices the researchers used the multi regression method and analyzed the data in eviws. For this purpose the researcher first checked the stationarity of the data through augmented dickey fuller test and then applied the Johansen cointegration Test and the cointegration results showed that there is a positive relationship among oil price, CPI and KSE-100 Index. Though the found results don't show the very strong relationship but it helps in concluding that oil prices have effect on CPI and KSE-100 Index
\end{abstract}

Keywords - Consumer price index, kse-100 Index, oil prices, cointegration

\section{Introduction}

Now day oil is the important for all of the countries to exist or move forward in the world so that each and every countries wants to produce own countries oil but most of the countries cannot get success. The year 2008 highest market volatility. Crisis after crisis seemed to hit the most of the countries that the result is the inflation rate increase so many times. Like in Pakistan the inflation in 2008 is $25.3 \%$ and oil is one of major factor which hit directly each and every commodity.

Pakistan is the oil importer country so that we spend more day by day and the prices of oil are also being high. The demand of oil increase day by day not only in Pakistan it is increase all over the world. If we are talking about the oil companies which importer the oil from outside the countries is raised like down news July2012 oil demand increase 89,203 tones to 597,954 tones. The prices of oil increase double ratio as compare to demand of oil. The demand of oil is not only increase in Pakistan but this challenge is facings most of the other countries. $1.3 \%$ world demand grow per year by 2030 and the developing countries demand increase $70 \%$ and $2.5 \%$ demand increase notably India and China. The main reason is that some countries has the ability to produce more but uncertain political situation

The consumer price index is very important indicator for looking the economy position of the country the investors who invest in the stock exchange keep eye on the inflation rate because it effect
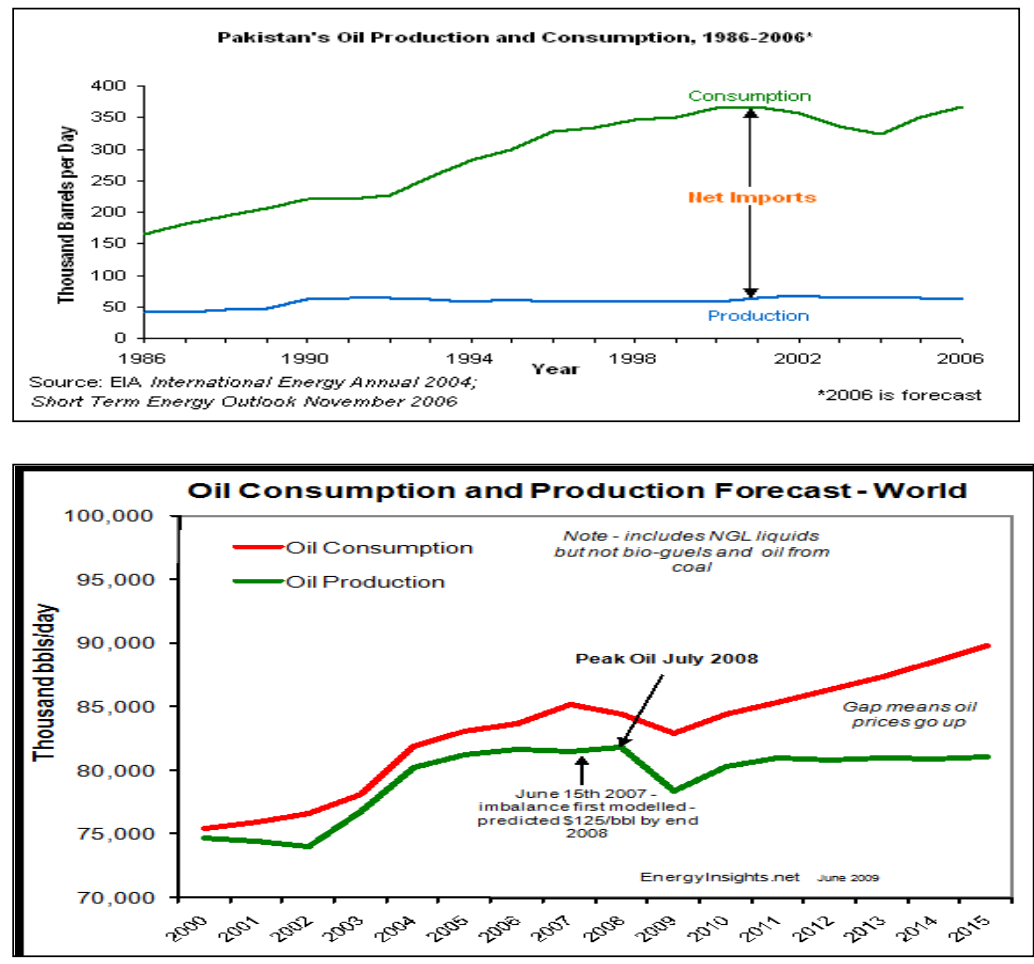
the investor investment and their return and they want to evaluate the risk factor in the society and also the profit margin. The high inflation rate means the high interest rate make difficult conditions for investors the raised in inflation means the difficult condition to survive in the market Pakistan inflation rate in November 2012 was recorded 6.9\% according to the government report Pakistan averaged Inflation Rate 10.55. But most of the people are not agree with the above figure. 


\begin{tabular}{|c|c|c|c|}
\hline Years & GDP(billion US \$) & Exchange Rate US/RS & Inflation \\
\hline $\mathbf{2 0 0 7}$ & 127.5 & 60.659 & 7.6 \\
\hline $\mathbf{2 0 0 8}$ & 143.201 & 70.415 & 20.29 \\
\hline $\mathbf{2 0 0 9}$ & 163.89 & 81.79 & 13.65 \\
\hline $\mathbf{2 0 1 0}$ & 161.98 & 85.18 & 13.88 \\
\hline $\mathbf{2 0 1 1}$ & 174.99 & 86.31 & 11.92 \\
\hline
\end{tabular}

Stock exchange is very important for all the countries it play very vital role for the development of the financial sector. Pakistan has (KSE) Karachi Stock Exchange, (LSE) Lahore Stock Exchange and (ISEI) Islamabad Stock Exchange three major stock exchange.

The KSE contribute vital role in development of the country. Stock exchanges provide the plate form where all investor are fully participate not only local investor. So that the foreigner investors are investing the new business came to exist now this is positive sign for the development in the country.

\section{Literature Review}

Now a day change in oil prices tend to change each and every factor Bwo-Nung Huang, Chin-Wei Yang, and Bi-Juan Lee (2007) "The Changing Effects of Oil Price Changes on Infla-tion" the framework of Mork's (1989) asymmetrical model and examine the relationship between the oil prices changing effect the inflation rate and also the stock exchange. Pet-tengill et al. (1995), Kaul and Seyhun 1990), Hess and Lee (1999), Sadorsky (1999), Lutz Kilian, Isakov (1999), Fletcher (2000), Hodoshima et al. (2000), Tang and Shum Lee and Ni (2002); (2003), Akram, 2004; Cunado and Gracia,(2005);Davis and Haltiwang-er,(2001)Cheolbeom Park, (2007), Chen and Chen, (2007); carried out the similar studies found that there is a significant positive relationship between the oil prices, stock exchange and inflation rate. The most of the research shows positive result for the influ-ence of oil on other factor like CPI stock market, inflation gold silver and many others factor which depend on increase or decrease oil prices. Bwo-Nung Huang, Chin-Wei Yang, and Bi-Juan Lee In (1) (pre-1986:12) asymmetric responses of inflation rate rates to real oil price increases and decreases but this relation was very short. Bwo-Nung Huang, Chin-Wei Yang, and Bi-Juan Lee In (2) (1987:01-1998:12) immediate responses on inflation due oil prices changes and this relation was larger than first period. And impact of oil increase was larger than the decrease in oil prices. And Bwo-Nung Huang, Chin-Wei Yang, and Bi-Juan Lee(2007) in (3) (post 1999:01) period the change in oil prices changes to the inflation was unmistakable in both the period and result was same as the second period and the oil prices has more effect in the last ten years.

In the Middle East the demand of oil increases very quickly and prices of oil are also jump it very soon the drop in stock prices this all happened due to change the political distribution may trigger all factor to change evidence in Kilian (2006c). And resources industries have negative sensitivity or less significant for the Banking industry, Paper, Packaging, and Transport industries. And this evidence was supported the model Dutch disease." Notably, was confirmed that some industries management needed to aware the consequent risk.

The increase in oil prices effect different from country to country and some researcher confirmed the result through the studies by taking the different variable and these re-search showed almost the same result Faff and Brailsford (1999) Robert W. Faffa,, Timothy J. Brailsfordb (1999), Sadorsky (1999) and in research paper Kaul and seyhun (1990) and Sadorsky (1999), Papapetrou (2001), and Hong et al.(2002), in this paper "Oil price risk and the Australian stock market "investigate the period (1983-1996. And the result con-firms the predictions the positive sensitivity observed for gas and oil. And resources industries have negative sensitivity or less significant for the Banking industry, Paper, Packaging, and Transport industries. And this evidence was supported the model Dutch disease." Notably, was confirmed that some industries management needed to aware the consequent risk.

The international stock markets was also be the effected the due to fluctuate oil prices and it effect in exchange rate. Ravichandran, Khalid Abdullah Alkhathlan (2010) investigate the oil impact on GCC Stock Market, Adiqa Kiani (2010) investigate the effect of oil on Pakistan economy growth." in this paper he was used time series method and investigate the impact of change in crude oil prices, gold prices on different countries exchange rate United States, Germany, Japan, Taiwan, and China vs. US dollar as well as correlation among these variable. The result Johansen co-integration test show that, one to two co-integration relations the united state and the rest of the group this indicates that exchange rates, gold prices, exchange rate and national stock relation exist long stable equilibrium. Thought Granger causality shows that the Taiwan stock prices and crude oil have two way feedback relationships between these two variables. And Taiwan stock price was leading by exchange rate from USD to NT; crude oil prices and gold prices was leading the exchange rate. While Taiwan stock prices and gold prices was mutually independent. 
(Dependent Variable)

(Independent Variable)

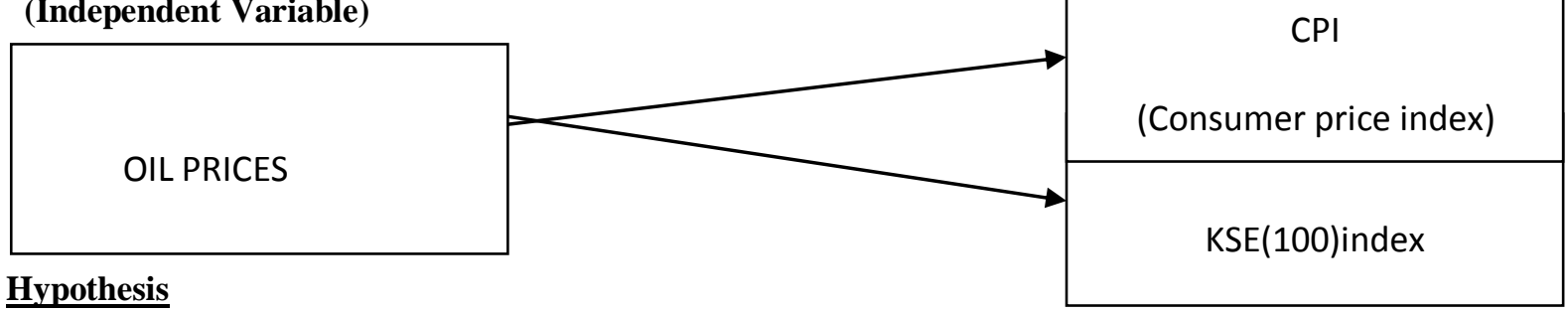

$\mathrm{HO}_{a}$ : There is positive a relationship between oil and stock exchange

$H_{l a}$ : There is no relationship between oil and stock exchange

$\mathrm{HO}_{b}$ : There is positive a relationship between oil and Inflation rate

$H_{l b}$ : There is no relationship between oil and Inflation rate

\section{Theoretical Framework}

In this study we are going to discuss the relationship between KSE (100) index and CPI (consumer price index) on change here in oil price, and here (100) index and CPI (consumer price index) are dependent variable and change in oil prices is independent variable.

\subsection{Methodology}

- Type of Data: The type of data in this research is Secondary data because it provides opportunity to study raw material and it provides necessary background about the studies that has being done and its result. And it also helps the researcher to compare or confirm the results.

- Variables: There are two variable independent and dependent oil prices independent variable and KSE 100 index, CPI, Exchange rate, dependent variable.

- Time: The time period of research data start from January2007 to August 2012 Source of data: The oil prices data collected by (index mundi), The CPI data collect by

- Sample: In this research the data is collected monthly from January2007 to August 2012. There are three variable are used in this research CPI, KSE 100- index, and Oil prices.

- Model: Multiple regressions are a statistical technique used for finding the relationship among the variable. The independent and dependent variable have any positive or negative impact between each other.

(1) $\mathbf{Y}=\mathbf{a}+\square \mathbf{1 X 1}+\square \mathbf{2 X} \mathbf{2}+\square$

$\boldsymbol{Y}=$ oil prices $a=$ con $\quad \boldsymbol{\beta} 1=$ change in $\mathrm{CPI}$,

$\boldsymbol{X 1}=$ value of $\mathrm{CPI}, \quad \boldsymbol{\beta 2}=$ change in $\mathrm{KSE} 100$ index

$\boldsymbol{X} \mathbf{2}=$ value of $K S E, \quad \boldsymbol{e}=$ Error term

- Tool: After collection the data these three variable (oil prices, KSE 100 index, and Inflation rate) the Eview software help to apply the test the unit root test to know that is this data is significant or not and the result showed that the data is significant

Augmented Dickey-Fuller Test

$1^{\text {st }}$ difference

Table \#1

\begin{tabular}{|l|l|l|l|}
\hline Variable/Test & Intercept & Trend and intercept & None \\
\hline Stock Market & -6.48 & -6.3 & -6.5 \\
\hline Oil Prices & -4.73 & -4.69 & -4.78 \\
\hline Inflation rate & -6.8 & -6.75 & -6.86 \\
\hline
\end{tabular}

Table \#1 Augmented Dickey-Fuller Test help to know that the data is stationary or not, but the result showed that all three variable (stock market, oil prices, inflation rate) data are stationary on $1^{\text {st }}$ difference.

Table \#2

Johansen Cointegration Test Summary

\begin{tabular}{|l|l|l|l|l|l|}
\hline Data Trend: & None & None & Linear & Linear & Quadratic \\
\hline $\begin{array}{l}\text { Rank or } \\
\text { No. of CEs }\end{array}$ & $\begin{array}{l}\text { No Intercept } \\
\text { No Trend }\end{array}$ & $\begin{array}{l}\text { Intercept } \\
\text { No Trend }\end{array}$ & $\begin{array}{l}\text { Intercept } \\
\text { Trend }\end{array}$ & $\begin{array}{l}\text { Intercept } \\
\text { Trend }\end{array}$ & $\begin{array}{l}\text { Intercept } \\
\text { Trend }\end{array}$ \\
\hline Akaike Information Criteria by Model and Rank \\
\hline $\mathbf{0}$ & -14.53529 & -14.53529 & -14.41184 & -14.41184 & -14.29231 \\
\hline $\mathbf{1}$ & -14.83487 & -15.02311 & -14.93089 & -14.90107 & -14.81221 \\
\hline
\end{tabular}




\begin{tabular}{|l|l|l|l|l|l|}
$\mathbf{2}$ & -15.03776 & -15.19716 & -15.13618 & -15.07939 & -15.01864 \\
\hline $\mathbf{3}$ & -15.01205 & -15.28293 & -15.25285 & -15.18273 & -15.15231 \\
\hline $\mathbf{4}$ & -14.83101 & -15.12935 & -15.12935 & -15.0399 & -15.0399 \\
\hline
\end{tabular}

Table \#2 the test Akaike Information Criteria by Model and Rank showed that the test which applied on this collected data and result showed that it lies on quadratic, intercept trend.

Table \#3

\section{Johansen Cointegration Test}

\begin{tabular}{|l|l|l|l|l|}
\hline Eigenvalue & $\begin{array}{l}\text { Likelihood } \\
\text { Ratio }\end{array}$ & $\begin{array}{l}\text { 5 Percent } \\
\text { Critical Value }\end{array}$ & $\begin{array}{l}\text { 1 Percent } \\
\text { Critical Value }\end{array}$ & $\begin{array}{l}\text { Hypothesized } \\
\text { No. of CE(s) }\end{array}$ \\
\hline 0.53694 & 111.8458 & 54.64 & 61.24 & None $* *$ \\
\hline 0.366458 & 62.57223 & 34.55 & 40.49 & At most $1^{* *}$ \\
\hline 0.318645 & 33.36082 & 18.17 & 23.46 & At most $2 * *$ \\
\hline 0.128545 & 8.805797 & 3.74 & 6.4 & At most $3 * *$ \\
\hline
\end{tabular}

$*(* *)$ denotes rejection of the hypothesis at $5 \%(1 \%)$ significance level

L.R. test indicates 4 cointegrating equation(s) at $5 \%$ significance

Table \#3 The result showed that both null hypothesis are acceptance and $\mathrm{HO}_{a}$ proved that positive relationship between the oil and stock exchange and also $\mathrm{HO}_{b}$ showed that positive relationship between the oil and inflation.

Table \#4

Johansen Cointegration Test

\begin{tabular}{|c|c|c|c|c|}
\hline Variable & Coefficient & Std. Error & t-Statistic & Prob. \\
\hline OIL & 0.418988 & 0.153469 & 2.73011 & 0.0082 \\
\hline Inflation & -2.849767 & 1.28074 & -2.225093 & 0.0296 \\
\hline $\mathrm{C}$ & 0.029397 & 0.019041 & 1.543903 & 0.1275 \\
\hline R-squared & 0.158130 & & $\begin{array}{l}\text { Mean dependent var } \\
\text { S.D. dependent var }\end{array}$ & 0.005721 \\
\hline Adjusted R-squared & 0.131821 & & 0.125455 & \\
\hline S.E. of regression & 0.116894 & & Akaike info criterion & -1.411356 \\
\hline
\end{tabular}

Table \#4 The Johansen Cointegration Test result showed that the oil prices have the positive and significant impact on the stock market and inflation. If the oil prices increase it affect the stock market return so that the inflation rates are also effect the stock market return. If the inflation rate increases in the market that effect the stock market returns investors and also the investors.

\section{Conclusion}

The oil is one of the most important factors affecting the economy of the world so that the demand of oil increase day by day and its prices increase double as the demand. This research paper result shown that the increase in oil prices effect the stock market positively same result as Kilian (2006c), and the time period in this research is (january2007 to August 2012).and collect the data through the secondary secure by ADT result confirm the positive relation and the energy sector are one of most important sector which play vital role for the development of the country. The oil importers countries are effecting more due to increase in crude oil in all over the world. The increase prices in energy sector effect most of the other sectors for example the most of the transports depend on the oil the increase in oil prices the transports charges are also be increase which effect the companies performance and stock return.

The second finding increase inflation rate effect the market return which create the difficult environment for the investors to survive in the market. The most of the countries are trying to control the inflation rate because it reflects the investors to invest in the local market. The inflation rates are also be reflect the risk factor in the market so that the government needed to maintain the inflation rate in the country which attract the foreign investor to invest. The inflation rate shown the economy position of the country because if the inflation rate of the country graph shown stability it is positive sign for the investors to get sure market return that the investors calculate before the investment.

Most of the countries focus the energy sector so that the oil one of the major sources for the energy sector so that the increase in oil prices and the demand of oil both increase very rapidly and the research result confirm that the increase in prices of oil effect the energy sector and it effect the stock market and oil prices have the positive and significant impact on the stock market. The result are also confirm that the increase inflation rate effect the stock market return. 


\section{References}

[1] Adven (2011), "History of the Karachi Stock Exchange (KSE)", available at: www.advfn.com/StockExchanges/history/KSE/KarachiStockExchange.html (accessed 08 January 2011)

[2] Miller, M. H., \& Upton, C. W. (1985b). The pricing of oil and gas: some further results. Jounal of Finance 40, 1009-1018

[3] Huang, B.N., M.J. Huang, and H.P. Peng (2005), "The Asymmetry of the Impact of Oil Price

[4] Shocks on Economic Activities: An Application of the Multivariate Threshold Model," Energy Economics, 27, 455-476

[5] Sharma, G.D., Mahendru, M. (2010). "Impact of Macro-Economic Variables on Stock Prices in India", Global Journal of Management and Business Research, Vol. 10 Issue 7, pp.19-26

[6] Wikipedia (2001), "Karachi Stock Exchange", available at: http://en.wikipedia.org/wiki/Karachi_Stock_Exchange

[7] Wikipedia (2001), KSE-100 Index, available at: http://en.wikipedia.org/wiki/KSE100_Index

[8] Ratanapakorn, O. and Sharma, S.C. (2007), "Dynamic Analysis between the US Stock Returns and the Macroeconomic Variables', Applied Financial Economics, Vol.17 No. 4-6, pp.369-377

[9] Karachi Stock Exchange (2011), “Karachi Stock Exchange website', available at: http://www.kse.com.pk/ (accessed 29 September 2011)

[10] Graham, S. (2001). "The Price of Gold and Stock Price Indices for the United States", Adrienne Roberts FT Personal Finance, pp.14

[11] De Gregorio, J., O. Landerretche, and C. Neilson (2007), "Another Pass-Through Bites The Dust? Oil Prices and Inflation," Economia, 7(2), 155-196.

[12] Bernanke, B.S., M. Gertler, and M. Watson (1997), "Systematic Monetary Policy and the Effects of Oil Price Shocks," Brookings Papers on Economic Activity, (1), 91-157.

[13] Perry Sadorsky(1999), Oil price shocks and stock market activity, Energy Economics, 21(5), 449-469

[14] Moore, G.H. (1990). Gold Prices and a Leading Index of Inflation, Challenge, Vol. 33 No.4, pp.52-56 